\title{
Synthesis of Graphite Paste/Molecularly Imprinted Polymer (MIP) Electrodes Based on Polyeugenol as a Glucose Sensor with Potentiometric Method
}

\author{
Muhammad Cholid Djunaidi ${ }^{*}$, Mei Dian Risda Afriani ${ }^{1}$, Gunawan ${ }^{1}$, and Miratul Khasanah ${ }^{2}$ \\ ${ }^{1}$ Department of Chemistry, Faculty of Science and Mathematics, Diponegoro University, \\ Jl. Prof. Soedharto SH, Tembalang, Semarang 50275, Indonesia \\ ${ }^{2}$ Department of Chemistry, Faculty of Science and Technology, Universitas Airlangga, \\ Campus C, Jl. Dr. Ir. H. Soekarno (MERR), Surabaya 60115, Indonesia
}

\author{
*Corresponding author: \\ email: choliddjunaidi@live.undip.ac.id \\ Received: August 23, 2020 \\ Accepted: April 4, 2021 \\ DOI: $10.22146 /$ ijc. 58964
}

\begin{abstract}
Diabetes mellitus is a chronic disease in which the body is unable to metabolize carbohydrates, fats, and proteins. In this study, eugenol was polymerized and then contacted with glucose and crosslinked using polyethylene glycol diglycidyl ether (PEGDE). The resulted PE-Glucose-PEGDE was eluted using ethanol to form MIPGlucose. It was then characterized by FTIR, SEM, electrodes using the Eutech 510 potentiostat and UV-Vis spectrophotometer. The result of polyeugenol synthesis is a reddish-brown powder with a yield of $99.90 \%$ and a molecular weight of $6318.033 \mathrm{~g} / \mathrm{mol}$. $U V$-Vis spectrophotometer analysis showed that the contacted glucose was 2152.505 ppm. SEM results showed differences in the surface morphology of the material, indicating the formation of cavities in MIP and ESM, while no cavities are found in NIP and ESN. The electrode optimization resulted in the best composition ratio of MIP 1 mol: paraffin: graphite, respectively of 20:35:45. The resulting electrode has a Nernst factor of 20.24 $\mathrm{mV} /$ decade with a measurement range of $10^{-5}-10^{-1} \mathrm{M}$, a limit of detection value of 8.363 $\times 10^{-5} \mathrm{M}$, and the value of the selectivity coefficient $\left(K_{i j}\right)$ of the electrodes in a $\left(10^{-5}-10^{-1}\right)$ $M$ fructose solution was 0.3733; 0.23048; 0.17864; 0.12359; 0.1073.
\end{abstract}

Keywords: polyeugenol; imprinted polymer; electrode; glucose; potentiometry

\section{- INTRODUCTION}

Diabetes mellitus is a chronic disease in which the body is not able to metabolize carbohydrates, fats, and proteins. This is caused by the increase of the glucose level in the blood due to a very progressive decrease in insulin secretion. Blood glucose is the simplest form of carbohydrates that is adsorbed into the blood fluids through digestion. Blood glucose levels are monitored by the pancreas and regulated directly by insulin with normal limits of $70-140 \mathrm{mg} / \mathrm{dl}$.

Determination of glucose levels has been carried out, including the Nelson-Somogyi method with spectrophotometry which is based on the formation of brick-red complex compounds from the reaction between glucose and complex reagents [1]. However, this method has a weakness; it is less selective because reagents can give a positive response to reducing other compounds than glucose, such as fructose and galactose. In 2018, Ratnayani et al. [2] analyzed glucose and fructose in cottonwood honey samples using the HPLC method. This method shows more specific results and has higher selectivity than other methods in determining glucose and fructose, but the operational costs are also quite high.

An alternative method that can be used is the potentiometric electrode. Potentiometry is a sample analysis based on the measurement of cell potential at zero current [3]. Previous research has used the potentiometric method to analyze urea and creatinine [4-5]. In potentiometry, there are two types of electrodes, the working electrodes and reference electrodes. The working electrode has a function as a sensor for the compound that is being analyzed [6]. Making the working electrodes in determining the type of sample is very important because it can produce 
sensor components as an accurate and selective analysis instrument. This electrode is based on molecularly imprinted polymer (MIP), where this polymerization technique is formed from functional monomers, templates, solvents, initiators, and crosslinker agents that react around the template molecules [7-8]. MIP has high selectivity, good mechanical strength, and good resistance to acids, alkalis, organic solvents, high pressure, and temperature.

Eugenol is a nonpolar organic compound and is found in almost $80 \%$ of all plants in Indonesia. Eugenol has three functional groups that are bound to its structure, namely allyl, hydroxyl, and methoxy groups. Allyl groups can be polymerized into polyeugenol, and hydroxyl groups can be synthesized into new compounds that have groups with a greater reactivity level, such as carboxylates and esters [9]. Research conducted by Djunaidi and Astuti regarding MIP-glucose using polyeugenol as a polymer and PEGDE as a MIP crosslink showed good resistance to organic solvents and inorganic acids [10]. The resulting MIP also showed good selectivity to glucose compared to non-imprinted polymer (NIP) by not absorbing fructose even in simultaneous solutions.

The advantage of using the potentiometric analysis method is the existence of a working electrode that is simple and easy to operate because it uses relatively cheap equipment that is a potentiometer ( $\mathrm{mV}$ meter). The purpose of this study was to synthesize glucose sensor electrodes and determine the optimum composition of the electrode synthesized polyeugenol-based graphite paste/MIP as a potentiometric glucose sensor and determine the Nernst factor, measurement range, detection limit, and coefficient of selectivity on the glucose sensor.

In this study, the synthesis of MIP was done with eugenol as a monomer, polyethylene glycol diglycidyl ether (PEGDE) as a crosslinking agent, $1 \mathrm{M} \mathrm{NaOH}$ as a catalyst, and a graphite electrode which has the ability to conduct current. The MIP modified graphite electrode is expected to improve the performance of the potentiometric sensor in determining glucose, including the Nernst factor, measurement range, detection limit, and selectivity coefficient, so that the formed electrode could provide excellence in glucose analysis.

\section{- EXPERIMENTAL SECTION}

\section{Materials}

The materials used in this research were eugenol p.a, $\mathrm{BF}_{3} \mathrm{O}\left(\mathrm{C}_{2} \mathrm{H}_{5}\right)$, polyethylene glycol diglycidyl ether (PEGDE), D-Glucose, and L-Fructose from SIGMA Aldrich, chloroform p.a, Methanol p.a, anhydrous $\mathrm{Na}_{2} \mathrm{SO}_{4}$, paraffin, graphite, $\mathrm{NaOH}, \mathrm{KNa}$-tartrate, 3,5dinitrosalcylic acid, phenol, $\mathrm{Na}_{2} \mathrm{SO}_{3}$, ethanol, $\mathrm{Na}_{2} \mathrm{HPO}_{4}$, $\mathrm{NaH}_{2} \mathrm{PO}_{4}, \quad \mathrm{CH}_{3} \mathrm{COOH}, \quad \mathrm{CH}_{3} \mathrm{COONa}$ from Merck, Germany, aquabidest from Bratachem, and Ag wire.

\section{Instrumentation}

The tools and instruments used in this research were laboratory glass equipment (Herma and Pyrex), reflux Set, 100 mesh sieve, pestle and mortar, analytical scales (Ohaus), magnetic bar, hotplate stirrer (LabTech CO.LTD), pH paper, micropipette tip, oven (Kirin), FTIR (Shimadzu Prestige 21), potentiostats (Eutech 510), UV-Vis spectrophotometer (LW-V- 200-RS), Ubbelohde viscometer, and SEM-EDX (Phenom Pro X Desktop with EDX).

\section{Procedure}

\section{Synthesis of polyeugenol}

A total of $5.8 \mathrm{~g}$ of eugenol in a three-neck flask was added with $0.25 \mathrm{~mL}$ of $\mathrm{BF}_{3}$-diethyl ether for every $1 \mathrm{~h}$ until $1 \mathrm{~mL}$ was added, while the mixture was stirred. After $16 \mathrm{~h}$, the polymerization reaction was stopped by adding $1 \mathrm{~mL}$ of methanol. The gel formed was dissolved with $30 \mathrm{~mL}$ of chloroform and washed with aquabidest until it reached neutral $\mathrm{pH}$. The solution was dried by adding anhydrous $\mathrm{Na}_{2} \mathrm{SO}_{4}$ and then evaporated at room temperature. The precipitate formed was dried, weighed, and analyzed by FTIR.

\section{Polyeugenol contacting with glucose}

The synthesized polyeugenol was contacted with glucose to make glucose imprinted polymer (glucose template). It was carried out by adding $0.5 \mathrm{~g}$ of polyeugenol to $10 \mathrm{~mL}$ of glucose solution with a concentration of $7500 \mathrm{ppm}$ and then stirred for $6 \mathrm{~h}$. It was then filtered, dried, and characterized using FTIR. 


\section{Synthesis of molecularly imprinted polymer (MIP)- glucose}

As much as $0.3 \mathrm{~g}$ of polyeugenol-glucose in a threeneck flask were added with $0.96 \mathrm{~g}$ of PEGDE and $20 \mathrm{~mL}$ of $1 \mathrm{M} \mathrm{NaOH}$, then refluxed to a temperature of $80-90{ }^{\circ} \mathrm{C}$ for $15 \mathrm{~min}$, and dried in an oven at $115^{\circ} \mathrm{C}$ for $6 \mathrm{~h}$. Then, it was sieved with a 100 Mesh pass sieve. $0.2 \mathrm{~g}$ of polyeugenol-glucose-PEGDE was washed with ethanol for $24 \mathrm{~h}$ and then characterized by FTIR and SEM-EDX [10].

\section{Synthesis of non-imprinted polymer (NIP)}

In a three-neck flask, as much as $0.3 \mathrm{~g}$ of polyeugenol were added with $0.96 \mathrm{~g}$ of PEGDE, $20 \mathrm{~mL}$ of $1 \mathrm{M} \mathrm{NaOH}$. The mixture was refluxed to a temperature of $80-90{ }^{\circ} \mathrm{C}$ for $15 \mathrm{~min}$ and dried in an oven at $115^{\circ} \mathrm{C}$ for $6 \mathrm{~h}$. It was then sieved through a 100 mesh sieve. Then, $0.2 \mathrm{~g}$ of polyeugenol-glucose-PEGDE was washed with ethanol for $24 \mathrm{~h}$ and characterized by FTIR and SEM-EDX.

\section{Synthesis of active graphite}

Active graphite is prepared chemically using $\mathrm{NaOH}$ as an activator. Graphite was immersed in $0.5 \% \mathrm{NaOH}$ and then let still at room temperature for $24 \mathrm{~h}$. After that, it was filtered and heated in an oven at $105^{\circ} \mathrm{C}$ for $3 \mathrm{~h}$. This active graphite is used as a carbon paste electrode material.

\section{Synthesis of graphite paste/MIP-glucose electrode}

The working electrode for glucose analysis was prepared by filling $3 / 4$ of the micropipette tube with molten solid paraffin. Previously, the silver wire that was used to connect the electrodes with the potentiometer was sanded and then inserted into the micropipette tube. Next, the remaining part of the micropipette tube is filled with a mixture of solid paraffin, graphite, and MIP that has been heated to form a paste. Tube filling was carried out by pressing so that the tube is completely filled with material, then the end of the electrode surface is rubbed using HVS paper. This process is summarized as in Fig. 1.

\section{Characterization of graphite paste/MIP electrode}

The characterization carried out included functional group analysis using FTIR, surface morphology analysis using SEM, calculating the potential value using the Eutech 510 potentiostat and the reference electrode, $\mathrm{Ag} / \mathrm{AgCl}$.

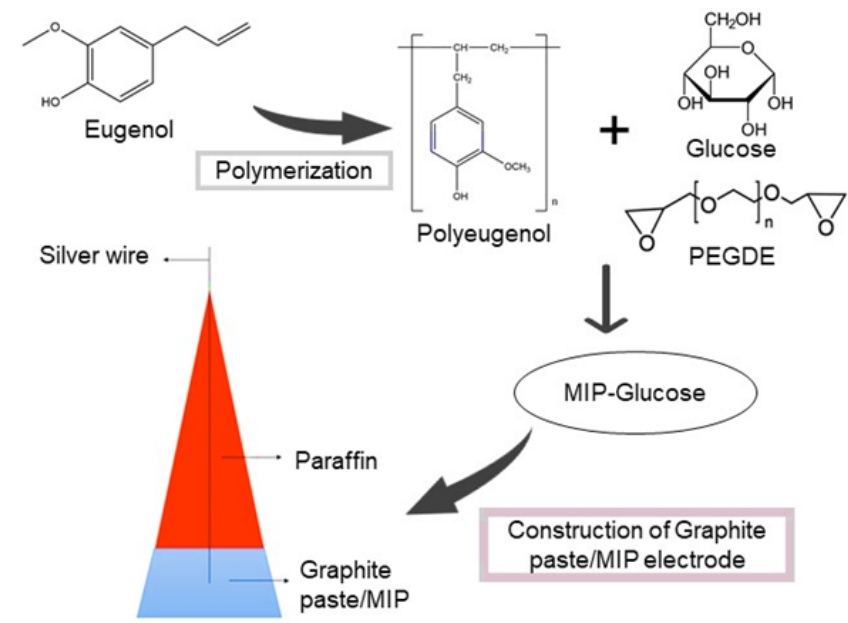

Fig 1. Graphite paste/MIP electrode synthesis

\section{- RESULTS AND DISCUSSION}

Preliminary analysis studies prior to electrode selectivity included analysis of eugenol polymerization result using FTIR, polyeugenol molecular weight measurements, and UV-Vis spectrophotometry analysis. The result of polymerization of eugenol is in the form of orange polyeugenol powder with a yield of $99.90 \%$ and a molecular weight of $6318.033 \mathrm{~g} / \mathrm{mol}$, which was determined by the viscosity method using the Ubbelohde viscometer. Furthermore, FTIR analysis was carried out to determine the differences in groups between eugenol and the synthesized polyeugenol; the result can be seen in Fig. 2 and Table 1.

Furthermore, the resulting polyeugenol was subjected to contact with glucose and crosslinked with polyethylene glycol diglycidyl ether, and the results of MIP-Glucose were analyzed using a UV-VIS spectrophotometer, and the results from the duplo test showed that the glucose adsorbed on the polyeugenol was $34.70 \%$. After that, the MIP that had been eluted with ethanol solvent was removed, filtered then the residue was analyzed using a UV-Vis spectrophotometer, and the results from the duplo test showed that the glucose released in MIP was $96.94 \%$. The results of the FTIR analysis were aimed at seeing the differences in groups and peaks that appeared on polyeugenol-glucose-PEGDE, MIP, NIP, ESM, and ESN. The FTIR result can be seen in Fig. 3. 


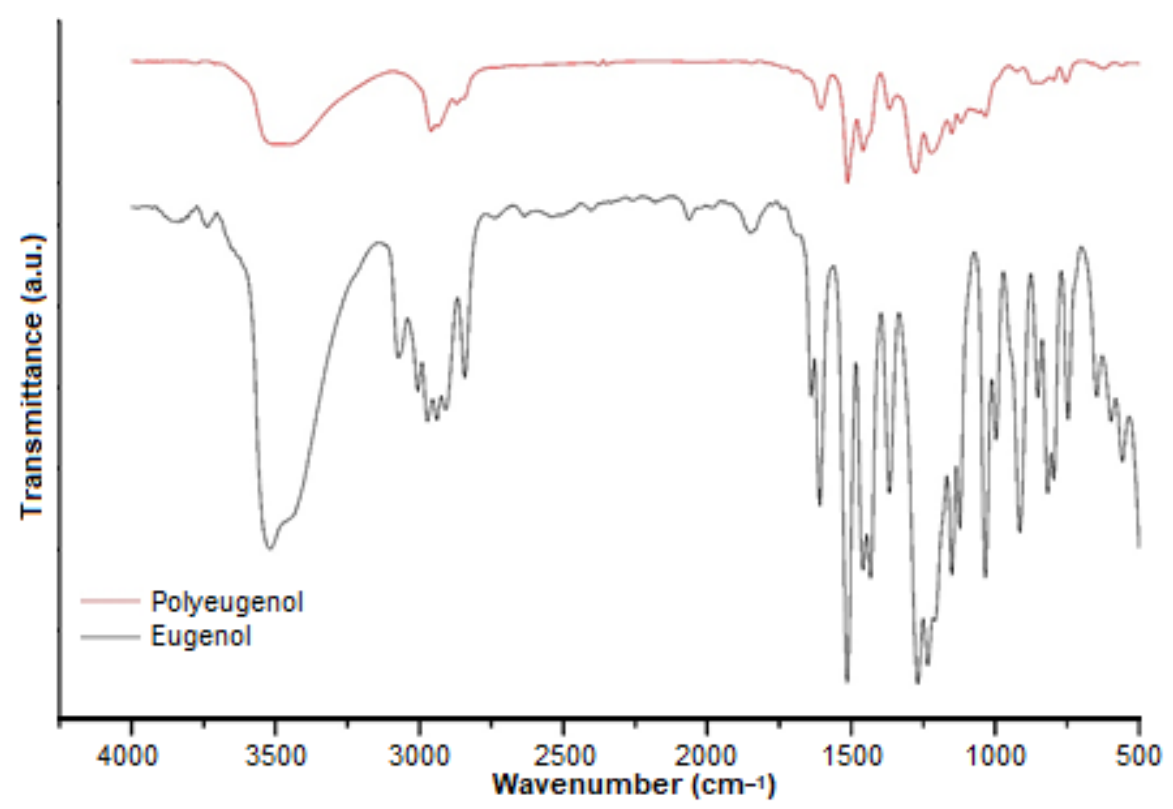

Fig 2. Graph of FTIR comparisons of eugenol and polyeugenol

Table 1. FTIR comparisons of eugenol and polyeugenol

\begin{tabular}{llll}
\hline Absorbance $\left(\mathrm{cm}^{-1}\right)$ & Functional groups characteristic & Eugenol & Polyeugenol \\
\hline 3514.7 & Hydroxyl $(\mathrm{O}-\mathrm{H})$ & Presence & Presence \\
2932 & Saturated Carbon $(\mathrm{C}-\mathrm{C})$ & Presence & Presence \\
1509 and 1603.08 & Aromatic $(\mathrm{C}=\mathrm{C})$ & Presence & Presence \\
1432.53 & Methylene $\left(-\mathrm{CH}_{2}-\right)$ & Presence & Presence \\
1620 and 1630 & Allyl $(\mathrm{C}=\mathrm{C})$ & Presence & Not presence \\
995 and 910 & Vinyl $\left(\mathrm{CH}=\mathrm{CH}_{2}\right)$ & Presence & Not presence \\
873.74 & Substituted Aromatic & Presence & Presence \\
\hline
\end{tabular}
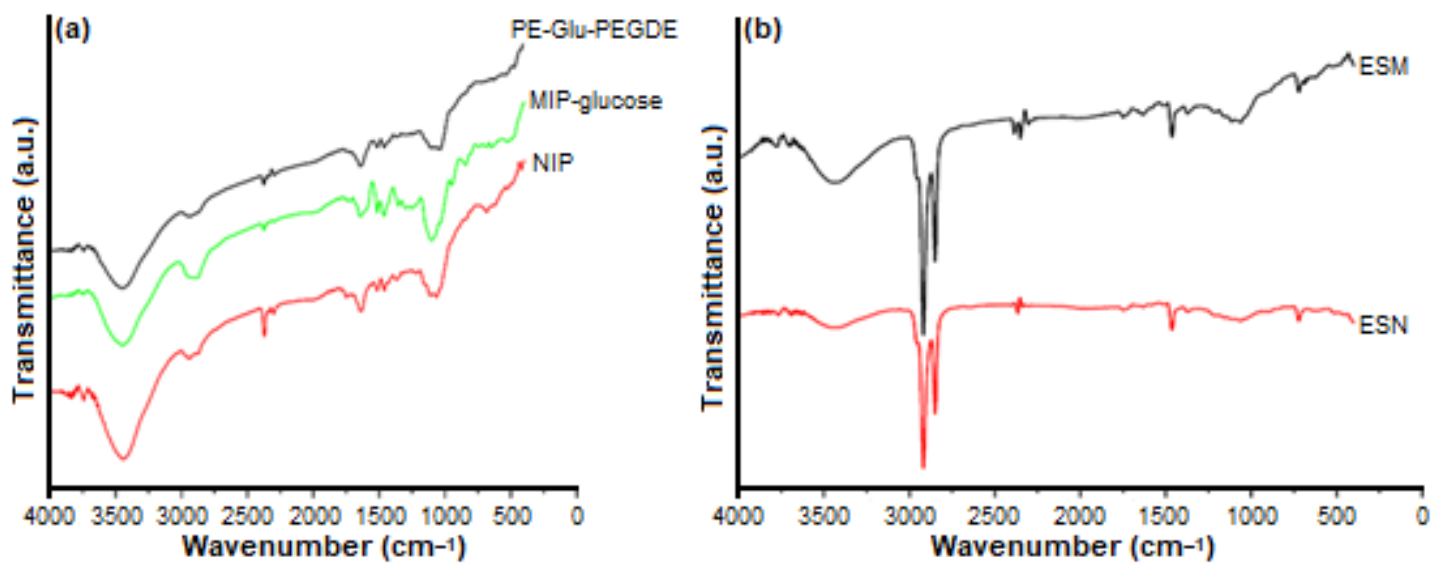

Fig 3. FTIR comparisons of (a) MIP and NIP (b) ESM and ESN

SEM-EDX analysis in Fig. 4 showed the morphological differences between MIP and NIP. In MIP, a cavity which is the template of glucose compounds are formed, while in NIP, the surface tends to be flat, no cavities are visible, and no template of glucose compounds is formed. The EDX analysis results were used to determine the elemental composition of $\mathrm{C}$ and $\mathrm{O}$ from MIP and NIP (Table 2), where the mass composition of 

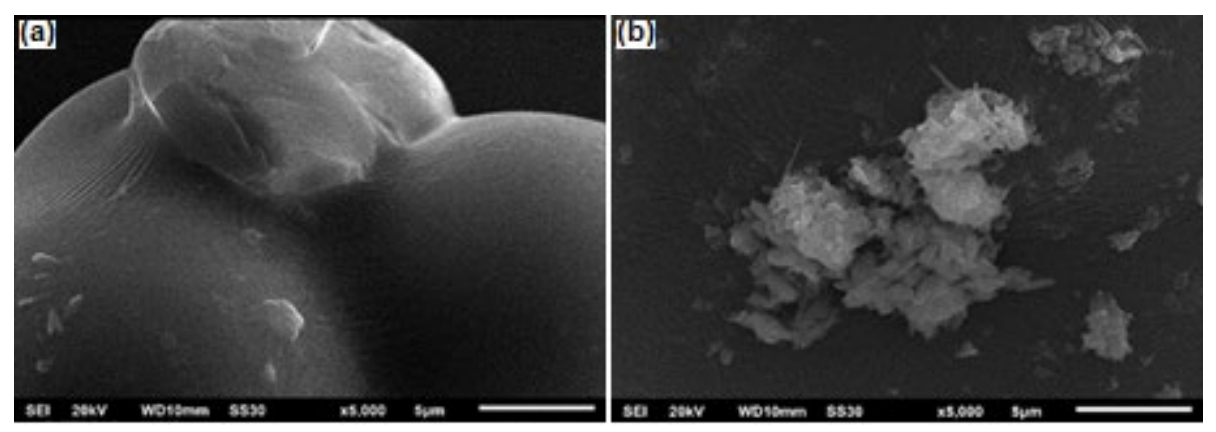

Fig 4. SEM results of (a) NIP (b) IP

$\mathrm{C}$ and $\mathrm{O}$ in MIP and NIP showed different results. In MIP, the mass of element $\mathrm{O}$ is greater than that of NIP. This is possible because there is no real difference because the glucose in MIP has been released.

Synthesis of the electrode was done by mixing MIP, active graphite, and paraffin with composition variation (\% mass) and $\mathrm{pH}$ variation. Based on Tables 3, 4, and 5, the electrodes that produce a good Nernst factor are the E5 electrodes, and the optimum $\mathrm{pH}$ is $\mathrm{pH} 7$ with a Nernst factor of $20.24 \mathrm{mV} /$ decade. E5 also shows a linearity value that is close to 1, which is 0.9996 . So, E5 is suitable for use in glucose analysis in this study.

The standard curve of glucose is obtained from measuring glucose solution $10^{-8} \mathrm{M}$ to $10^{-1} \mathrm{M}$ at the optimum $\mathrm{pH}$ of 7 using a graphite-MIP paste electrode. Measurements were done potentiometrically with an $\mathrm{Ag} / \mathrm{AgCl}$ comparison electrode. The potential data obtained can be seen in Table 6 .

Table 2. Element mass percentage in MIP and NIP

\begin{tabular}{ccr}
\hline \multirow{2}{*}{ Element } & \multicolumn{2}{c}{ Mass (\%) } \\
\cline { 2 - 3 } & MIP & NIP \\
\hline $\mathrm{C}$ & 63.51 & 65.31 \\
$\mathrm{O}$ & 35.02 & 29.46 \\
$\mathrm{Cl}$ & 1.24 & 1.31 \\
$\mathrm{Ca}$ & 0.23 & 0.22 \\
$\mathrm{Al}$ & - & 0.90 \\
$\mathrm{Cu}$ & - & 2.79 \\
\hline
\end{tabular}

Table 3. Factor Nernst data and measurement range in $\mathrm{pH} 3$

\begin{tabular}{|c|c|c|c|c|c|c|}
\hline \multirow{2}{*}{ Electrode Code } & \multicolumn{3}{|c|}{ Composition (wt.\%) } & \multirow{2}{*}{$\begin{array}{l}\text { Nernst Factor } \\
\text { (mV/decade) }\end{array}$} & \multirow{2}{*}{$\begin{array}{c}\text { Measurement } \\
\text { Range (M) }\end{array}$} & \multirow{2}{*}{$\begin{array}{c}\text { Linearity } \\
\text { (r) }\end{array}$} \\
\hline & MIP & Carbon & Paraffin & & & \\
\hline E1 & 0 & 65 & 35 & -14.3 & $10^{-8}-10^{-5}$ & 0.9531 \\
\hline $\mathrm{E} 2$ & 5 & 60 & 35 & -11 & $10^{-6}-10^{-3}$ & 0.9853 \\
\hline E3 & 10 & 55 & 35 & -8.62 & $10^{-6}-10^{-2}$ & 0.9866 \\
\hline $\mathrm{E} 4$ & 15 & 50 & 35 & -5.17 & $10^{-4}-10^{-1}$ & 0.9887 \\
\hline E5 & 20 & 45 & 35 & -2.9 & $10^{-7}-10^{-4}$ & 0.9397 \\
\hline E6 & 25 & 40 & 35 & -3.9171 & $10^{-7}-10^{-2}$ & 0.9606 \\
\hline
\end{tabular}

Table 4. Factor Nernst data and measurement range in $\mathrm{pH} 5$

\begin{tabular}{ccccccc}
\hline \multirow{2}{*}{ Electrode Code } & \multicolumn{3}{c}{ Composition (wt.\%) } & \multirow{2}{*}{$\begin{array}{c}\text { Nernst Factor } \\
\text { (mV/decade) }\end{array}$} & $\begin{array}{c}\text { Measurement } \\
\text { Range (M) }\end{array}$ & $\begin{array}{c}\text { Linearity } \\
(\mathrm{r})\end{array}$ \\
\cline { 2 - 4 } E1 & MIP & Carbon & Paraffin & & & \\
E2 & 0 & 65 & 35 & -19.7 & $10^{-4}-10^{-1}$ & 0.7741 \\
E3 & 5 & 60 & 35 & -4.7 & $10^{-5}-10^{-2}$ & 0.9625 \\
E4 & 10 & 55 & 35 & -4.7143 & $10^{-6}-10^{-1}$ & 0.9198 \\
E5 & 15 & 50 & 35 & -4.75 & $10^{-7}-10^{-1}$ & 0.9784 \\
E6 & 20 & 45 & 35 & -3.4 & $10^{-4}-10^{-1}$ & 0.9966 \\
\hline
\end{tabular}


Table 5. Factor Nernst data and measurement range in $\mathrm{pH} 7$

\begin{tabular}{|c|c|c|c|c|c|c|}
\hline \multirow{2}{*}{ Electrode Code } & \multicolumn{3}{|c|}{ Composition (wt\%) } & \multirow{2}{*}{$\begin{array}{l}\text { Nernst Factor } \\
\text { (mV/decade) }\end{array}$} & \multirow{2}{*}{$\begin{array}{c}\text { Measurement } \\
\text { Range }(\mathrm{M})\end{array}$} & \multirow{2}{*}{$\begin{array}{c}\text { Linearity } \\
\text { (r) }\end{array}$} \\
\hline & MIP & Carbon & Paraffin & & & \\
\hline E1 & 0 & 65 & 35 & 9.49 & $10^{-5}-10^{-1}$ & 0.8143 \\
\hline E2 & 5 & 60 & 35 & 2.9393 & $10^{-8}-10^{-2}$ & 0.6572 \\
\hline E3 & 10 & 55 & 35 & 13.09 & $10^{-8}-10^{-4}$ & 0.9668 \\
\hline $\mathrm{E} 4$ & 15 & 50 & 35 & 4.1 & $10^{-7}-10^{-4}$ & 0.9689 \\
\hline E5 & 20 & 45 & 35 & 20.24 & $10^{-5}-10^{-1}$ & 0.9996 \\
\hline E6 & 25 & 40 & 35 & 9.0357 & $10^{-7}-10^{-1}$ & 0.9404 \\
\hline
\end{tabular}

Based on the potential data obtained, a standard glucose curve was made with the log glucose concentration as the $\mathrm{x}$-axis and the potential as the $\mathrm{y}$-axis. The curve of the relationship between the log of glucose concentration and potential $(\mathrm{mV})$ can be seen in Fig. 5 . Furthermore, the concentration range curve that gives a linear line is called the standard curve of glucose solutions that were used to find out the equation of the line that shows the value of the Nernst factor as in Fig. 6 .

\section{Result of Determination of Measurement Range}

The measurement range is the concentration range that produces a linear potential response, and the value of the Nernst factor is close to theoretical. Determination of the measurement range is carried out on all electrodes, namely E1-E6. From the measurement results of the measurement range of the graphite-MIP paste electrode, which can be seen in Table 5, the electrode that has a Nernst factor close to the theoretical value is E5, namely $20.24 \mathrm{mV} /$ decade, and the measurement range is $\left(10^{-5}-\right.$ $\left.10^{-1}\right) \mathrm{M}$.

\section{Result of Determination of Detection Limits}

The detection limit is the lowest concentration limit that an electrode can respond to [11]. The detection limit is determined from the intersection of linear lines with non-linear lines on the glucose standard curve [12]. The linear line equation is $y=20.24 \mathrm{x}+252.86$ while the non-linear line $y=8.3 x^{2}+96.3 x+425$. The results of the detection limit measurement on the graphite-MIP paste electrode are shown in Fig. 7.

Table 6. The results of the measurement of the graphiteMIP paste electrode potential at $\mathrm{pH} 7$

\begin{tabular}{cc}
\hline Log [Glucose] & Potential (mV) \\
\hline-8 & 140 \\
-7 & 142 \\
-6 & 146 \\
-5 & 151 \\
-4 & 172.6 \\
-3 & 192.1 \\
-2 & 213 \\
-1 & 232 \\
\hline
\end{tabular}

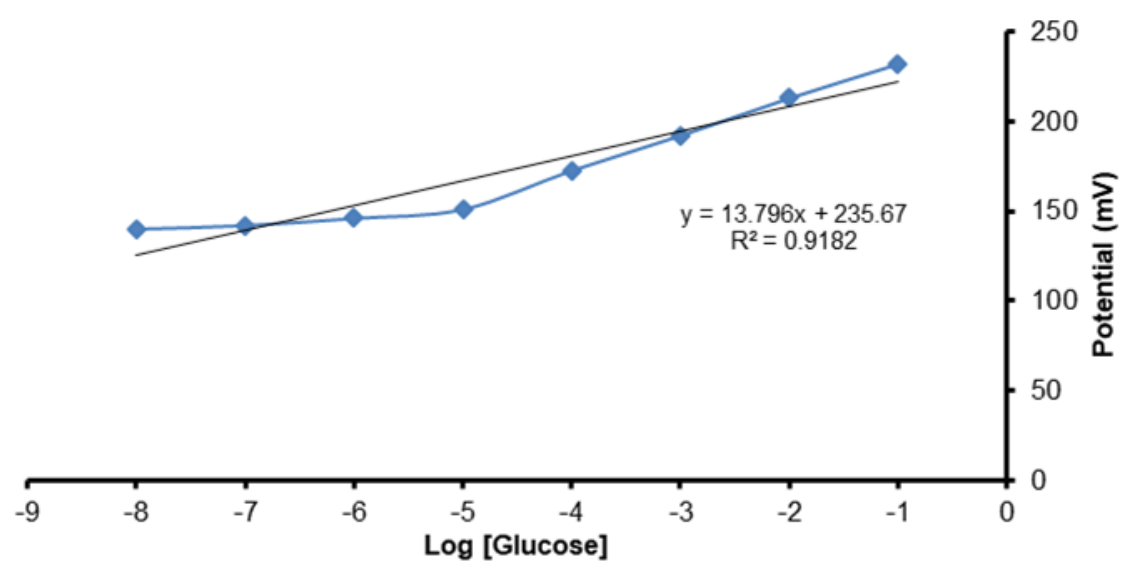

Fig 5. The correlation curve between log [Glucose] and potential (mV) 


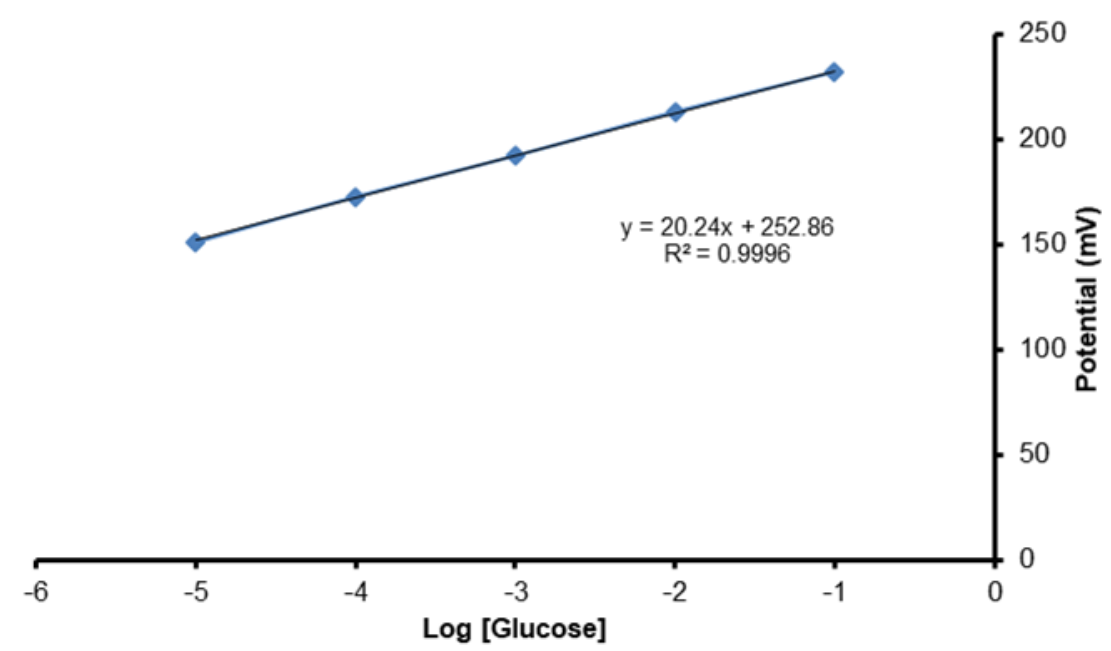

Fig 6. Standard curve of Glucose solution

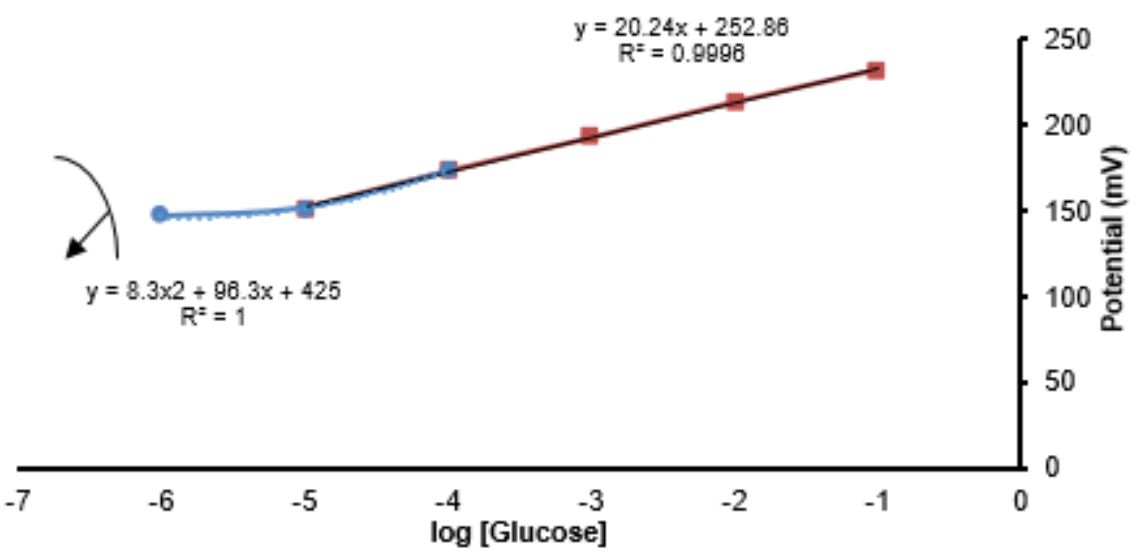

Fig 7. Detection limit measurement curve

The detection limit on the graphite-MIP paste electrode is $8.363 \times 10^{-5} \mathrm{M}$, which means that the electrode is theoretically able to detect the presence of glucose up to a concentration of $8.363 \times 10^{-5} \mathrm{M}$ with the Nernst factor, which still meets the theoretical value. The detection limit produced by the graphite-MIP paste electrode can be used for glucose analysis in blood serum with a normal concentration of $70-110 \mathrm{mg} / \mathrm{dL}$ or the equivalent of $3.88 \times 10^{-3}-6.10 \times 10^{-3} \mathrm{M}$, while the glucose concentration of patients with diabetes mellitus exceeds $200 \mathrm{mg} / \mathrm{dL}$ or equivalent to $1.11 \times 10^{-2} \mathrm{M}$. The calculation of detection limits is determined from the intersection of the linear lines with the non-linear lines on the glucose standard curve [12]. The linear line equation is $y=20.24 \mathrm{x}$ +252.86 while the non-linear line is $y=8.3 x^{2}+96.3 x+$ 425 , produces a limit of detection (LOD) capable of detecting the presence of glucose up to a concentration of
$8.363 \times 10^{-5} \mathrm{M}$. Some comparisons of the LOD result by our work and previous research is reported in Table 7.

The glucose sensor works because of a redox reaction in the electrode system where the detected glucose undergoes a half-redox reaction. At the electrode, a potential difference appears because there is a redox reaction in glucose, namely the oxidation of glucose, while the reduction occurs at the electrode. Glucose oxidation will release $\mathrm{H}^{+}$which is then captured as a sensor because the electrode functions as an $\mathrm{H}^{+}$ (acid) sensor.

Electrode selectivity for glucose analysis in this study was studied using the match potential method (MPM). The value of the selectivity coefficient $\left(K_{\mathrm{ij}}\right)$ of the electrodes in a $10^{-5}-10^{-1} \mathrm{M}$ fructose solution was $0.3733 ; 0.23048 ; 0.17864 ; 0.12359 ; 0.1073$. A selectivity test was carried out with fructose because fructose has the 
Table 7. Comparison data of the LOD of our work with the previous reports

\begin{tabular}{llccc}
\hline Method & Electrode Material & Linear range (M) & LOD (M) & Reference \\
\hline Amperometry & Carbon paste/GOx silica & $5 \times 10^{-4}-9 \times 10^{-3}$ & $1.5 \times 10^{-4}$ & {$[13]$} \\
Amperometry & $\begin{array}{l}\text { Carbon paste/selenium nanoparticle- } \\
\text { mesoporous silica composite (MCM-41) }\end{array}$ & $1 \times 10^{-5}-2 \times 10^{-3}$ & $1 \times 10^{-4}$ & {$[14]$} \\
Potentiometry & $\begin{array}{l}\text { Poly (terthiophene benzoic acid) (pTBA) } \\
\text { layered-AuZn alloy oxide (AuZnOx) }\end{array}$ & $1.6 \times 10^{-3}-2.7 \times 10^{-2}$ & $9.6 \times 10^{-4}$ & {$[15]$} \\
Potentiometry & $\begin{array}{l}\text { Poly (3-aminophenyl boronic acid-co-3- } \\
\text { octylthiophene) }\end{array}$ & $5 \times 10^{-3}-5 \times 10^{-2}$ & $5 \times 10^{-4}$ & {$[16]$} \\
Potentiometry & Carbon nanotube on gold printed & $10^{-3}-10^{-1}$ & $1 \times 10^{-4}$ & {$[17]$} \\
Potentiometry & Carbon paste/IZ & $10^{-4}-10^{-2}$ & $5.6 \times 10^{-5}$ & {$[18]$} \\
Potentiometry & Carbon paste/MIP (Polyeugenol) & $10^{-5}-10^{-1}$ & $8.363 \times 10^{-5}$ & This work \\
\hline
\end{tabular}

most similar structure to glucose. If the sugars have structures that are so different from glucose, they are not detected by the glucose sensor. Based on the $\mathrm{K}_{\mathrm{ij}}$ value data, it can be concluded that the presence of fructose does not interfere with the potentiometric analysis of glucose using a graphite-MIP paste electrode because the resulting selectivity coefficient is less than one. If the $\mathrm{K}_{\mathrm{ij}}$ value is less than 1 then, the electrode is selective to the analyte being measured rather than the disruptor compound, and if the $\mathrm{K}_{\mathrm{ij}}$ value is bigger than 1, the electrode is selective to the disruptor compound than the measured analyte. If $K_{i j}=0$, then the foreign compound does not interfere [19-20].

\section{- CONCLUSION}

The optimum composition of graphite, MIP on the electrode using the mass ratio of graphite, paraffin, MIP is $45: 35: 20$ (wt.\%) with the optimum $\mathrm{pH}$ of the solution is pH 7 (with buffer settings). Potentiometric analysis of glucose using graphite-MIP paste electrodes resulted in a measurement range of $10^{-5}-10^{-1} \mathrm{M}$, and the Nernst factor of $20.24 \mathrm{mV} /$ decade. The optimum electrode produced has a detection limit of $8.363 \times 10^{-5} \mathrm{M}$. This electrode has a fairly good selectivity value, which is less than 1 .

\section{- REFERENCES}

[1] Shao, Y., and Lin, A.H.M., 2018, Improvement in the quantification of reducing sugars by miniaturizing the Somogyi-Nelson assay using a microtiter plate, Food Chem., 240, 898-903.

[2] Ratnayani, K. Dwi Adhi S., N.M.A., and Gitadewi, I. G.A.M.A.S., 2008, Penentuan kadar glukosa dan fruktosa pada madu randu dan madu kelengkeng dengan metode kromatografi cair kinerja tinggi, Jurnal Kimia, 2 (2), 77-86.

[3] Skoog, D.A., West, D.M., Holler, F.J., and Crouch, S.R., 2013, Fundamentals of Analytical Chemistry, $9^{\text {th }}$ Ed., Cengage Learning, Boston, MA.

[4] Liu, Y., Cánovas, R., Crespo, G.A., and Cuartero, M., 2020, Thin-layer potentiometry for creatinine detection in undiluted human urine using ionexchange membranes as barriers for charged interferences, Anal. Chem., 92 (4), 3315-3323.

[5] Lai, C.Y., Foot, P.J.S., Brown, J.W., and Spearman, P., 2017, Urea potentiometric biosensor based on a thiophene copolymer, Biosensors, 7 (1), 13.

[6] Kawahara, R., Sahatiya, P., Badhulika, S., and Uno, S., 2018, Paper-based potentiometric $\mathrm{pH}$ sensor using carbon electrode drawn by pencil, Jpn. J. Appl. Phys., 57 (4S), 04FM08.

[7] BelBruno, J.J., 2018, Molecularly imprinted polymers, Chem. Rev., 119, 94-119.

[8] Saylan, Y., Akgönüllü, S., Yavuz, H., Ünal, S., and Denizli, A., 2019, Molecularly imprinted polymer based sensors for medical applications, Sensors, 19 (6), 1279.

[9] Djunaidi, M.C., Khabibi, and Ulumuddin, I., 2017, Separation of $\mathrm{Cu}^{2+}, \mathrm{Cd}^{2+}$, and $\mathrm{Cr}^{3+}$ in a mixture solution using a novel carrier poly(methyl thiazoleethyl eugenoxy acetate) with BLM (bulk liquid membrane), IOP Conf. Ser.: Mater. Sci. Eng., 172, 012032.

[10] Djunaidi, M.C., and Astuti, Y., 2019, Synthesis, characterization and selectivity of molecularly 
imprinted polymer (MIP) glucose using polyeugenol as a functional polymer, Rasayan J. Chem., 12 (2), 809-821.

[11] Dinh, T.V., Choi, I.Y., Son, Y.S., and Kim, J.C., 2016, A review on non-dispersive infrared gas sensors: Improvement of sensor detection limit and interference correction, Sens. Actuators, B, 231, 529538.

[12] Puspitasari, H.I., 2012, Pembuatan dan karakterisasi elektroda selektif berbasis karbon nanopori/molecularly imprinted polymer untuk analisis glukosa dalam madu, Undergraduate Thesis, Department of Chemistry, Universitas Airlangga, Surabaya.

[13] Jędrzak, A., Rębiś, T., Klapiszewski, L., Zdarta, J., Milczarek, G., and Jesionowski, T., 2018, Carbon paste electrode based on functional GOx/silica-lignin system to prepare an amperometric glucose biosensor, Sens. Actuators, B, 256, 176-185.

[14] Yusan, S., Rahman, M.M., Mohamad, N., Arrif, T.M., Latif, A.Z.A., Mohd Aznan, M.A., and Wan Nik, W.S.B., 2018, Development of an amperometric glucose biosensor based on the immobilization of glucose oxidase on the Se-MCM-41 mesoporous composite, J. Anal. Methods Chem., 2018, 2687341.

[15] Kim, D.M., Cho, S.J., Cho, C.H., Kim, K.B., Kim, M.Y., and Shim, Y.B., 2016, Disposable all-solid-state
$\mathrm{pH}$ and glucose sensors based on conductive polymer covered hierarchical AuZn oxide, Biosens. Bioelectron., 79, 165-172.

[16] Çiftçi, H., Tamer, U., Teker, M.Ş., and Pekmez, N.Ö., 2013, An enzyme free potentiometric detection of glucose based on a conducting polymer poly (3-aminophenyl boronic acid-co-3octylthiophene), Electrochim. Acta, 90, 358-365.

[17] Alhans, R.A., Singh, A., Singhal, C., Narang, J., Wadhwa, S., and Mathur, A., 2018, Comparative analysis of single-walled and multi-walled carbon nanotubes for electrochemical sensing of glucose on gold printed circuit boards, Mater. Sci. Eng., C, 90, 273-279.

[18] Khasanah, M., Widati, A.A., Handajani, U.S., Harsini, M., Ilmiah, B., and Oktavia, I.D., 2020, Imprinted zeolite modified carbon paste electrode as a selective sensor for blood glucose analysis by potentiometry, Indones. J. Chem., 20 (6), 13011310.

[19] Cattrall, R.W., 1997, Chemical Sensors, Oxford University Press, New York.

[20] Aulia, M.S., Abdurrahman, M., and Putrada, A.G., 2019, Pendeteksian kadar glukosa dalam darah pada gejala diabetes tipe 1 menggunakan algoritma K-Nearest Neighbor dengan metode nafas, SMARTICS, 5 (1), 14-21. 